\title{
Do We Need a Psychology of Women in the Islamic World?
}

\author{
Joseph Vandello ${ }^{1}$
}

Published online: 29 October 2016

(C) Springer Science+Business Media New York 2016

\begin{abstract}
In these brief remarks I use the present collection of papers to this special issue on women in the Muslim World to address broader questions about a psychology of women in Islam. I discuss what might constitute Muslim culture, arguing that the combination of the themes of religiosity, collectivism, tightness, conservatism, gender differentiation and patriarchy, and honor offer a good starting point as a taxonomy for a distinct Islamic culture. Next, I discuss the present contributions to this special issue in the broader context of challenges faced by women in Muslim cultures, which are often among the most gender unequal in the world. Finally, I offer some suggestions for advancing cultural research on women in the Islamic World.
\end{abstract}

Keywords Islamic women $\cdot$ Culture $\cdot$ Gender $\cdot$ Sexism

Despite some earlier influential voices, psychology really began to take seriously the idea of culture only a generation ago. Mainstream psychology prior to the 1980s was shaped by the fact that most researchers, most participants, and most editors of major journals were members of Western, individualistic cultures (Triandis 2010). Research in cultural psychology grew exponentially in the 1980s and 1990s, leading to an increasing appreciation of diversity and the ways in which unique ecological, economic, social, and historical forces can influence fundamental human psychology (Cole 1998). This has been a welcome and important evolution in the field. However, despite its emergence as a formal sub-discipline,

Joseph Vandello

vandello@usf.edu

1 Department of Psychology, University of South Florida, 4202 E Fowler Ave, Tampa, FL 33620, USA cultural psychology remains overly focused on individualism and collectivism and comparisons of Far East Asian versus Western European and U.S. populations (Cohen 2009). Much less is known about other cultural frames of references, although that is changing. The time is ripe for this special issue on women in the Islamic World. The papers in this special issue help to shed light on a large but understudied cultural group. The issues covered in this special issue-workforce participation, work engagement, sexism, honor, violence, religiosity, attitudes toward childlessness, postmenopausal depression-illustrate the diverse concerns facing women in the Muslim world.

In these brief remarks, I will suggest what I see as the main challenges and benefits of studying women in the Islamic World. I will discuss how the papers in this special issue address some of these challenges and suggest further work that might advance the field. Before discussing women in Islam and how the present series of papers brings into focus the complexities and challenges of women in the Islamic world, I would first like to address a more fundamental conceptual and methodological issue: How can we define something as broad and varied as the Islamic World?

\section{Defining the Culture of the Islamic World}

People practice Islam in diverse cultures around the globe, making it difficult to identify a distinct Islamic culture. Muslims comprise nearly a quarter of the planet, second only to Christians (Pew Research Center 2012). Sizeable Muslim populations exist on every continent. The highest Muslim concentrations are in the Northern Africa/Middle East region, where $93 \%$ of the population is Muslim (Desilver 2013). By sheer population, there are more Muslims in the Asia-Pacific region than anywhere else (Desilver 2013). Not only are 
Muslims a culturally and ethnically heterogeneous group, Islam as a set of religious beliefs and practices is also quite diverse across regions, ranging from more conservative, fundamentalist strains to more liberal, reform strains (Said and Sharify-Funk 2003). Complicating matters further, Islamic identity intersects with other identities. Although we often contrast the Islamic world with the "West," for many who identify both as Westerners and Muslims, this is a distinction without meaning (Mirza 2013). Given this diversity, is it even accurate to think of Islam as a culture?

\section{Defining Themes of Islamic Culture}

Painting with broad strokes a picture of billions of people undoubtedly oversimplifies and, at worst, runs the risk of caricature and stereotyping. It is important to recognize nuance and variation, both across Muslim cultures and within. Nonetheless, I believe that it is accurate to talk about an overarching Islamic culture, one that transcends race, ethnicity, and national boundaries. What does this culture look like? What are its defining psychological features? In the following sections, I summarize what I believe are six central themes. This is not necessarily an exhaustive list, but together the six themes capture what might reasonably considered the major defining psychological features of Islamic culture.

\section{Religiosity}

An obvious starting point for a culture defined by a religious denomination is the importance of religiosity. For many Muslims, religion is a central organizing theme of everyday life (Abu-Raiya 2013). It shapes one's attitudes and moral judgments, public and private behaviors, and relationships between women and men. It is reinforced through behavioral rituals, namely the key practice of praying five times a day. Until fairly recently, psychology has suffered from a blindspot by ignoring religion as a central belief system shaping people's worldviews (Ysseldek et al. 2010). References to religion or religiosity remain rare in most social psychology texts. Religion is not just an individual belief system; it is also a form of culture that binds people across time and place (Cohen 2009; Cohen and Hill 2007). Religion not only offers individual psychological benefits (e.g., coping with death anxiety, creating meaning in life), but also provides solutions to social and ecological problems faced by social groups (Shariff et al. 2014). It is a system of shared beliefs, values, and norms that is transmitted across generations and places (Fiske et al. 1998). Religious culture is reinforced by customs, dress, and shared holidays. In this sense, religion is culture, and Islam (or Judaism, Hinduism, or Christianity) is as much a cultural identity as a belief system. Of course, religious customs vary from place to place, and Arab, Persian, Northern African, Asian, and North American versions of Islam differ. So, although there is an overarching Islamic culture, there are also cultures within this culture.

Supporting the idea that Islam is a culture that stretches beyond the political boundaries of nations, most Muslims feel a strong shared identity with fellow Muslims around the globe. For instance, Muslims strongly endorse the belief that they belong to a larger Islamic nation (Abu-Raiya et al. 2008), a sense of shared identity that may distinguish it from some other religious groups.

\section{Collectivism}

Predominantly Islamic cultures are nearly all characterized by high degrees of collectivism. Although the collectivism of the Islamic world does not distinguish it from other collectivist cultures, it is a central feature of most all Muslim societies. Whereas collectivism in some cultures is directed broadly at the state or ethnic group, Islamic collectivism appears more narrowly focused on the family, both immediate and extended (Abu-Lughod 1999). This can take the form of a sort of tribalism, as exemplified in Bedouin society (Abu-Lughod 1999). In Islamic cultures, important decisions are almost always considered with respect to the implications for one's family.

\section{Tightness}

Tight (in contrast to loose) cultures are formal and disciplined with many stated social norms (Pelto 1968). Members of the culture are expected to follow the rules, and there is relatively little tolerance for deviation (Gelfand 2012; Gelfand et al. 2011). Islamic cultures are tight cultures. Islam emphasizes an ethical code of conduct adduced from the Qura'n (AbuRaiya 2013). Not surprisingly, predominantly Islamic cultures like Pakistan, Malaysia, and Turkey tend to score quite high on empirical measures of cultural tightness (Gelfand et al. 2011).

\section{Conservatism}

Owing to the centrality of religion in everyday life, Islamic cultures tend to be socially conservative. This emphasis on conservatism is captured in cross-cultural research on human values. For instance, Schwartz's $(1992,2012)$ influential theory of basic human values contrasts a dimension of conservatism (e.g., security, tradition, conformity) with openness to change (e.g., self-direction, stimulation, hedonism). Not surprisingly, religiosity relates positively to giving priority to conformity and traditional values as well as negatively to giving priority to hedonism, self-direction, and stimulation values in studies of European Christians and Jews (Roccas and Schwartz 1997; Schwartz and Huismans 1995). Extrapolating from the individual level to the cultural level 
and to Muslim populations, we would expect that members of Islamic cultures will prioritize values reflecting conservatism.

Similarly, work by Inglehart and Welzel (2015) from the World Values Surveys asserts that there are two major value dimensions that order cultures around the world: Traditional versus secular-rational and survival versus self-expression values. Empirical work from the World Values Surveys (2016) project confirms Muslim societies' social conservatism because predominantly Muslim cultures cluster in a group that is high in both traditional and survival values, in contrast to the more secular English speaking and Protestant European nations, which score high in secular-rational and self-expressive values.

\section{Gender Differentiation and Patriarchy}

Perhaps one of the biggest differences between the Islamic world and the Western world (and most relevant to this special issue's focus on women) is the status of women and relationships between the sexes. Islamic cultures are, by and large, relatively patriarchal, in which men are heads of households and women are expected to be subordinate, although the degree of patriarchy is a matter of debate and varies across Muslim societies (Moghadam 2004; Rizzo et al. 2007). Westerners, who emphasize individual freedoms, autonomy, and equality (in theory if not in practice), often have trouble with cultural notions of gender hierarchy. They see women's subordination as oppression. In contrast, the family model of hierarchy in Islamic cultures places strong emphasis on unity and identity. The high status, powerful members of family are obliged to protect and care for the weak. It is a relationship not just of domination but also of affection and mutual concern (Abu-Lughod 1999). Inequality is thus rationalized and legitimized, but also embedded within a system of moral order. This protective paternalism is central to Glick and Fiske's (1996) benevolent sexism construct, and it helps explain why women in Muslim societies often strongly endorse benevolent, chivalrous forms of honor (see especially, Glick et al. 2015).

\section{Honor}

Closely related to gender-based hierarchies is the concept of honor. Honor is the moral basis of this gender hierarchy (AbuLughod 1999), and it also reflects and reinforces collectivism by emphasizing the maintenance of strong family ties. One's honor is based on social image or reputation; it is one's worth in one's own eyes and the eyes of others (see Nisbett and Cohen 1996, for studies of southern U.S. honor; Pitt-Rivers 1965, for studies of Mediterranean honor; Rodriguez Mosquera et al. 2002 for studies of Spanish honor; and AbuOdeh 2011, for a discussion of Arab honor). Across honor cultures, having honor means being respected by others, but women and men acquire and protect honor differently (Vandello and Cohen 2003, 2008). For men, honor carries with it the responsibility to protect one's family. Men gain honor through enforcing their will upon others (with force if necessary), but also through acts of generosity. For women, honor is focused more on avoiding actions that might bring shame to one's self and one's family.

Honor norms are central to most Muslim cultures, owing perhaps in part to the gender inequality justifying ideology of Islam (again, see Glick et al. 2015). However, the honor ideology is not specific to Islam. For instance, Caffaro et al. (2016) find that predominantly Christian Cameroon was the most strongly endorsing of honor-related violence of their cultural samples, even compared to Muslim Morocco.

Although my list may not be an exhaustive, together the six themes I summarized here (religiosity, collectivism, tightness, conservatism, gender hierarchy, and honor) form the basis of a recognizable and distinct Islamic culture. Future research might conceptually and empirically support, refute, or add to this list to help define the core psychological dimensions of Muslim identity.

\section{Gender in the Islamic World}

To discuss women in the Islamic world is to acknowledge some uncomfortable truths. The status of women in Muslim countries is among the poorest in the world. The World Economic Forum (2015) releases an annual Global Gender Gap Report that includes an index measuring women's political empowerment, educational and economic participation and opportunity, and health. Nineteen of the 20 lowest ranked countries in the index are predominantly Muslim. This highlights a need not only for a cultural psychology of Islam, but also for one that focuses on issues central to women's lives. The papers in this special issue bring focus to some of the gender-related problems and challenges associated with Islamic culture.

Both the papers by Caffaro et al. (2016) and Glick et al. (2015) highlight troublesome aspects of honor beliefs that can justify violence against women. Importantly, both consider contextual factors that can interact with culture in nonobvious ways. The paper by Glick and colleagues asks why women often support an ideological system that oppresses them. It is a nice example of how a cultural ideology such as honor may have different meanings for women and men. Women link the benevolent, paternalistic aspects of sexism with honor, whereas men link the more hostile, antagonistic aspects of sexism with honor. And the paper by Caffaro and colleagues highlights the importance of considering both nationality and religion when considering Islamic culture. Although the predominant religious affiliation of the participants in the study (Muslim versus Christian) had little influence on attitudes 
about honor-related violence of a father toward a daughter who secretly dated a boy, nationality did influence attitudes. Cultures in which patriarchal, and not just Islamic, ideology holds sway (Cameroon and Morocco) had more permissive attitudes about honor-related violence than did Italians.

The two papers also illustrate widely held cultural beliefs (often shared by both men and women) that women's sexuality is dangerously powerful and uncontrollable (cf. Baumeister and Twenge 2002; Valenti 2009). Sexual repression and control of women are the result of this belief. (Islam is of course not alone in problematizing sex, particularly female sexuality; see Orthodox Judaism and Roman Catholicism for other examples: Fisher 2006; Sontag 2001; Webber 1983.). Repressive practices that stem from seeing girls and women as dangerous are often most extreme in Muslim cultures - from clitoridectomies in northern Africa, to the ban on women driving in Saudi Arabia, to virginity tests common in many parts of the Middle East and Mediterranean, to the practice of marrying young girls to gain ownership over their sexuality (see Baumeister and Twenge 2002; Mernissi 1987).

One solution to cultural ambivalence to female sexuality may be to prioritize and prize marriage and having children. As Husnu (2016) shows in a sample of Turkish students in Cypress, Islamic religiosity predicted negative attitudes toward childlessness, and this relationship was mediated by benevolently sexist beliefs (which include beliefs that women should be pure and sexually chaste). Again, this was true for women as much as men. One question that the Husnu paper cannot answer is whether this relationship between religiosity and attitudes toward childlessness is specific to Muslim cultures, or whether religiosity in general stigmatizes women who choose to remain childless - a potential topic for future research.

Interestingly, as Jamil and Khalid's (2016) study of middleaged Pakistani women suggests, women's dangerous sexuality may come with an expiration date. As women age, and particularly once they are no longer able to bear children, they may be freed of some of the cultural restrictions placed on younger women, and this release may contribute to better psychological health. It would be interesting to contrast this cultural view with that of the West, in which women are highly sexually objectified (Fredrickson and Roberts 1997). Do older Western women feel similarly freed from these unrealistic and harmful constraints as well, or are views of aging more negative among women in the West where consumerist culture places such a high value on youth and physical appearance (Jeffreys 2014)?

Two other contributions to this issue focus on the influence of a conservative cultural ideology on women in the workplace. The papers highlight both how female employment can be a route to empowerment and autonomy and how cultural ideology can restrict that empowerment. Camgoz et al. (2016) explored feelings of job insecurity among a sample of Turkish banking employees. Most interestingly, they find that the relationship between job insecurity and turnover intentions is different for women and men. For women, unlike men, feelings of job insecurity related to losing job privileges was not a strong predictor of turnover intentions. The authors suggest that this may be due to a cultural context in which workplace discrimination against women is institutionalized and expected. This is a provocative claim, but one which is not tested directly. It will be important in future studies to test whether this pattern holds in other Muslim and non-Muslim societies in order to see if there is indeed something about culture that drives women's work expectations.

Sen et al.'s (2016) paper suggests how education and workforce participation can be a context of social change and a route to empowerment for women. Again examining a sample of women in Turkey, the authors find that employed women were more likely than were homemakers to be up-to-date on cancer screenings. The results raise some interesting questions about why the two groups of women differ in their health behaviors. Are employed women more educated about health risks? Are there differences between these two groups of women in attitudes about doctors and healthcare more generally? Do employed women have greater access to resources to get the screenings? Are employed women more likely to interact with other women who get regular health screenings so that a social norm develops for proactive health behaviors? Again, the precise role of culture in women's decision to take active health measures (or not) is unclear. It would be helpful in future research to directly measure cultural attitudes about health behaviors to begin to understand the role of culture in women's health.

Collectively, the six papers in this special issue demonstrate the wide range of issues important to women in the Islamic world. Although much of the focus is on negative aspects and challenges facing Muslim women, they also importantly show that there is a rich complexity of cultural views even within Muslim societies. To deny the problems of Islamic culture's views of women would be a mistake, but it would also be a mistake to focus only on these aspects. Focusing solely on the problematic views of women in Islam risks presenting an incomplete picture that misses the rich complexity and richness of Muslim culture.

\section{Looking Ahead: Suggestions for Future Research}

The papers in this issue suggest productive avenues for future research on Islamic women. I would like to end by using the present papers as a starting point to offer a few suggestions for how research on women in the Islamic world may best advance. 


\section{Multi-Nation Studies}

First, although some of the studies in this issue gathered data across nations, most took place within a single culture. Singlenation studies can serve as a valuable starting point to investigate cultural hypotheses, but they also have significant limitations. The contributions to this special issues do a good job of extending the diversity of samples in psychological research to understudied groups. But more attention could be paid to understanding the unique cultural forces at play. Single-culture studies raise questions about whether the results extend to other Muslim countries or beyond the Islamic world. Relatedly, single-culture studies make it difficult to tease apart precisely which aspects of culture (as opposed to non-cultural factors such as education or socioeconomic status) may be responsible for various outcomes. Future research would benefit from more large, multi-national studies, particularly ones that include understudied populations (e.g., Africa, Arab nations, Southeast Asia).

\section{Collaborations}

Of course, large multi-culture studies are costly and intensive efforts. One way to increase the number of such studies is to establish collaborations across cultures, particularly collaborations across Islamic and non-Islamic cultures. Such collaborations are important because they allow for the testing of culturally-specific hypotheses by examining variation within and outside of specific cultural contexts. It is hugely important that collaborators come from both within and outside the Islamic world. The former is needed because, as framed from the West, gender in the Islamic world can be too easily pathologized and exoticized; the latter, because it is important to observe a culture from outside to shine a light on what might otherwise be invisible or taken for granted from the inside.

\section{Theory Development}

Theory remains underdeveloped in much cultural research, but the present studies offer some important perspectives that may serve as a catalyst for theory-building efforts. For instance, what existing social-psychological theory might we draw upon to understand why Islamic women embrace a religion that often uses authoritarian practices to oppress them and stifle their sexuality and their sense of being? What psychological benefits of religious identity counter negative outcomes for women in particular? How do people reconcile what is often perceived as a clash between modern, "Western" values, and the more traditional, conservative values of the Islamic World?

\section{Accentuate the Positive}

Research focused on Islamic-based populations has skewed toward addressing problematic aspects (e.g., honor and violence, women's oppression). Although these are certainly important topics that deserve attention, the positive psychological aspects of Islamic culture are understudied and thus underappreciated. To take just one example, researchers studying cultural emphases on honor (myself included) have focused largely on honor's role in violence. But honor carries with it strong norms for hospitality and reciprocity. Future research in this area might examine these more positive aspects of honor. Despite the restrictions that Islamic culture places on women (particularly as perceived from the perspective of more liberal Western societies), Islam's role in most people's lives is mostly positive, consistently associated with measures of wellbeing (Abu-Raiya et al. 2008). These positive aspects deserve more attention.

\section{Immigration and Intersectional Identities}

Because Islamic populations extend to virtually all corners of the globe, Muslim identities intersect with other important cultural identities such as race, nationality, and sexual orientation (Rahman 2010; Zaal et al. 2007). And many Muslims are transplants from one culture to a new culture and thus identify with multiple cultures simultaneously (Jasperse et al. 2011). How do women fare when going from Islamdominated cultures to cultures in which Muslims are the minority? How do women experience and negotiate what may be incompatible gender norms within liberal democracies compared to home cultures? As well, other identities (e.g. ethnic minority status, sexual minority status) can interact with Muslim identities to predict unique psychological outcomes. For example, what are the experiences of LGBT individuals in Muslim societies, and how do they differ across more and less socially conservative cultures? These are important questions for future research.

\section{Conclusions}

I titled my paper "Do We Need a Psychology of Women in the Islamic World?," but as I hope to have made clear in these brief remarks, the papers in this special issue make a strong, obvious case for the need. The papers in this special issue are important for cultural psychology as a whole because they shift the field from its focus on East-West difference and a singular focus on individualism and collectivism. Culture centered on religion, honor, and traditional gender ideology has far-reaching implications for relationships, work, health, and well-being, and psychology is only beginning to address these issues. Furthermore, the focus on women is important 
because, as the present papers demonstrate, women face unique health and work-related challenges. Ideally, these articles will spur more researchers to study not just women in the Islamic World, but also more types of cultural variation among more types of cultures.

Compliance with Ethical Standards This manuscript complies with all ethical standards.

\section{References}

Abu-Lughod, L. (1999). Veiled sentiments: Honor and poetry in a Bedouin society. Berkeley, CA: University of California Press.

Abu-Odeh, L. (2011). Crimes of honor and the construction of gender in Arab societies. Comparative Law Review, 2, 1-47. Retrieved from http://www.comparativelawreview.unipg.it/index. php/comparative/article/view/47/44.

Abu-Raiya, H. (2013). The psychology of Islam: Current empirically based knowledge, potential challenges, and directions for future research. In K. I. Pargament (Ed.), APA handbook of psychology, religion, and spirituality: Context, theory, and research (Vol. 1, pp. 681-695). Washington, DC: American Psychological Association.

Abu-Raiya, H., Pargament, K. I., Mahoney, A., \& Stein, C. (2008). A psychological measure of Islamic religiousness: Development and evidence of reliability and validity. The International Journal for the Psychology of Religion, 18, 291-315. doi:10.1080 /10508610802229270.

Baumeister, R. F., \& Twenge, J. M. (2002). Cultural suppression of female sexuality. Review of General Psychology, 6, 166-203. doi:10.1037/1089-2680.6.2.166.

Caffaro, F., Mulas, C., \& Schmidt, S. (2016). The perception of honourrelated violence in female and male university students from Morocco, Cameroon, and Italy. Sex Roles. doi:10.1007/s11199015-0576-8. Advance online publication.

Camgoz, S. M., Ekmekci, O. T., \& Karapinar, P. B. (2016). Job insecurity and turnover intentions: Gender differences and the mediating role of work engagement. Sex Roles. doi:10.1007/s11199-016-0595-0. Advance online publication.

Cohen, A. B. (2009). Many forms of culture. American Psychologist, 64, 194-204. doi:10.1037/a0015308.

Cohen, A. B., \& Hill, P. C. (2007). Religion as culture: Religious individualism and collectivism among American Catholics, Jews, and Protestants. Journal of Personality, 75, 709-742. doi:10.1111 jj.1467-6494.2007.00454.x.

Cole, M. (1998). Cultural psychology: A once and future discipline. Cambridge, MA: Harvard University Press.

Desilver, D. (2013, June 7). World's Muslim population more widespread than you might think. Pew Research Center. Retrieved from http:/www.pewresearch.org/fact-tank/2013/06/07/worlds-muslimpopulation-more-widespread-than-you-might-think/.

Fisher, I. (2006, May 2). Ideals clash as Vatican rethinks ban on condoms. New York Times (pp. A1, A10).

Fiske, A. P., Kitayama, S., Markus, H. R., \& Nisbett, R. E. (1998). The cultural matrix of social psychology. In D. T. Gilbert, S. Fiske, \& G. Lindzey (Eds.), Handbook of social psychology (Vol. 2, 4th ed., pp. 915-981). Boston: McGraw-Hill.

Fredrickson, B. L., \& Roberts, T. (1997). Objectification theory: Toward understanding women's lived experiences and mental health risks. Psychology of Women Quarterly, 21, 173-206. doi:10.1111/j.14716402.1997.tb00108.x.
Gelfand, M. (2012). Culture's constraints: International differences in the strength of social norms. Current Directions in Psychological Science, 21, 420-424. doi:10.1177/0963721412460048.

Gelfand, M., Raver, J., Nishii, L., Leslie, L., Lun, J., Lim, B., \& Yamaguchi, S. (2011). Differences between tight and loose cultures: A 33-nation study. Science, 332, 1100-1104. doi:10.1126 /science.1197754.

Glick, P., \& Fiske, S. T. (1996). The ambivalent sexism inventory: Differentiating hostile and benevolent sexism. Journal of Personality and Social Psychology, 70, 491-512. doi:10.1037 /0022-3514.70.3.491.

Glick, P., Sakallı-Uğurlu, N., Akbaș, G., Metin Orta, I., \& Ceylan, S. (2015). Why do women endorse honor beliefs? Ambivalent sexism and religiosity as predictors. Sex Roles. doi:10.1007/s11199-0150550-5. Advance online publication.

Husnu, S. (2016). The role of ambivalent sexism and religiosity in predicting attitudes toward childlessness in Muslim undergraduate students. Sex Roles. doi:10.1007/s11199-016-0639-5. Advance online publication.

Inglehart, R., \& Welzel, C. (2015). The world values surveys cultural map of the world. World values surveys project. Retrieved from http://www.worldvaluessurvey.org/WVSContents.jsp.

Jamil, F., \& Khalid, R. (2016). Factors contributing to depression during peri menopause: Findings of a Pakistani sample. Sex Roles. doi:10.1007/s11199-016-0690-2

Jasperse, M., Ward, C., \& Jose, P. E. (2011). Identity, perceived religious discrimination, and psychological well-being in Muslim immigrant women. Applied Psychology, 61, 250-271. doi:10.1111/j.14640597.2011.00467.x.

Jeffreys, S. (2014). Beauty and misogyny: Harmful cultural practices in the west. New York: Routledge.

Mernissi, F. (1987). Beyond the veil: Male-female dynamics in modern Muslim society. Bloomington, IN: Indiana University Press.

Mirza, H. S. (2013). "A second skin": Embodied intersectionality. Transnationalism and narratives of identity and belonging among Muslim women in Britain. Women's Studies International Forum, 36, 5-15. doi:10.1016/j.wsif.2012.10.012.

Moghadam, V. M. (2004). Patriarchy in transition: Women and the changing family in the Middle East. Journal of Comparative Family Studies, 35, 137-162. Retrieved from http://connection.ebscohost. $\mathrm{com} / \mathrm{c} /$ articles/12190077/patriarchy-transition-women-changingfamily-middle-east.

Nisbett, R. E., \& Cohen, D. (1996). Culture of honor. Boulder, CO: Westview Press.

Pelto, P. J. (1968). The differences between "tight" and "loose" societies. Society, 5, 37-40.

Pew Research Center. (2012). The global religious landscape. Retrieved from http://www.pewforum.org/2012/12/18/global-religiouslandscape-exec/.

Pitt-Rivers, J. (1965). Honour and social status. In J. G. Peristiany (Ed.), Honour and shame: The values of Mediterranean society (pp. 1877). London, UK: Weidenfeld and Nicolson.

Rahman, M. (2010). Queer as intersectionality: Theorizing gay Muslim identities. Sociology, 44, 944-961. doi:10.1177 /0038038510375733.

Rizzo, H., Abdel-Latif, A.-H., \& Meyer, K. (2007). The relationship between gender equality and democracy: A comparison of Arab versus non-Arab Muslim societies. Sociology, 41, 1151-1170. doi: $10.1177 / 0038038507082320$.

Roccas, S., \& Schwartz, S. H. (1997). Church-state relations and the association of religiosity with values: A study of Catholics in six countries. Cross-Cultural Research, 31, 356-375. doi:10.1177 /106939719703100404.

Rodriguez Mosquera, P. M., Manstead, A. S. R., \& Fischer, A. H. (2002). The role of honor concerns in emotional reactions to offenses. 
Cognition and Emotion, 16, 143-163. doi:10.1080 /02699930143000167.

Said, A. A., \& Sharify-Funk, M. (Eds.). (2003). Cultural diversity and Islam. Lanham, MD: University Press of America.

Schwartz, S. H. (1992). Universals in the content and structure of values: Theory and empirical tests in 20 countries. In M. Zanna (Ed.), Advances in experimental social psychology (Vol. 25, pp. 1-65). New York: Academic Press.

Schwartz, S. H. (2012). An overview of the Schwartz theory of basic values. Online Readings in Psychology and Culture, 2. Retrieved from http://scholarworks.gvsu.edu/cgi/viewcontent. cgi?article $=1116 \&$ context $=$ orpc

Schwartz, S. H., \& Huismans, S. (1995). Value priorities and religiosity in four western religions. Social Psychology Quarterly, 58, 88-107. doi: $10.2307 / 2787148$.

Sen, C. K. N., Baruh, L., \& Kumkale, G. T. (2016). Beyond a paycheck: The influence of workforce participation on women's cancer screening in Turkey. Sex Roles. doi:10.1007/s11199-016-0611-4. Advance online publication.

Shariff, A. F., Purzycki, B. G., \& Sosis, R. (2014). Religions as cultural solutions to social living. In A. B. Cohen (Ed.), Culture reexamined: Broadening our understanding of social and evolutionary influences (pp. 217-238). Washington, DC: American Psychological Association.

Sontag, D. (2001, April 11 ). Women seize counseling role on "family purity." New York Times (pp. A4).

Triandis, H. C. (2010). Culture and psychology: A history of the study of their relationship. In S. Kitayama \& D. Cohen (Eds.), Handbook of culture and psychology (pp. 59-76). New York: Guilford Press.
Valenti, J. (2009). The purity myth. Berkeley, CA: Seal Press.

Vandello, J. A., \& Cohen, D. (2003). Male honor and female fidelity: Implicit cultural scripts that perpetuate domestic violence. Journal of Personality and Social Psychology, 84, 997-1010. doi:10.1037 /0022-3514.84.5.997.

Vandello, J. A., \& Cohen, D. (2008). Culture, gender, and men's intimate partner violence. Social and Personality Psychology Compass, 2, 652-667. doi:10.1111/j.1751-9004.2008.00080.x.

Webber, J. (1983). Between law and custom: Women's experience of Judaism. In P. Holden (Ed.), Women in religious experience: Cross-cultural perspectives (pp. 143-162). London, UK: Croom Helm.

World Economic Forum. (2015). The global gender gap report, 2015. Geneva, Switzerland: World Economic Forum. Retrieved from http://www3.weforum.org/docs/GGGR20115/cover.pdf.

World Values Surveys. (2016, September 23). Retrieved from http://www.worldvaluessurvey.org/wvs.jsp.

Ysseldek, R., Matheson, K., \& Anisman, H. (2010). Religiosity as identity: Toward an understanding of religion from a social identity perspective. Personality and Social Psychology Review, 14, 6071. doi: $10.1177 / 1088868309349693$.

Zaal, M., Salah, T., \& Fine, M. (2007). The weight of the hyphen: Freedom, fusion, and responsibility embodied by young MuslimAmerican women during a time of surveillance. Applied Developmental Science, 11, 164-177. doi:10.1080 /10888690701454674. 